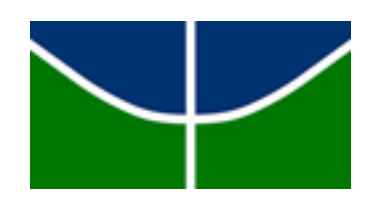

UNIVERSIDADE DE BRASÍLIA

FACULDADE DE COMUNICAÇÃO - FAC

TRABALHO DE CONCLUSÃO DE CURSO

DOCENTE: PROFA. DRA. DELCIA MARIA DE MATTOS VIDAL

\title{
GUIA DE BOAS PRÁTICAS DE COMUNICAÇÃO PARA LOJAS COLABORATIVAS
}

FELÍCIA FERNANDES MACEDO

BRASÍLIA

JUNHO DE 2017 
FELÍCIA FERNANDES MACEDO

\title{
GUIA DE BOAS PRÁTICAS DE COMUNICAÇÃO \\ PARA LOJAS COLABORATIVAS
}

\begin{abstract}
Memorial Descritivo do Trabalho de Conclusão de Curso apresentado ao curso de Comunicação Organizacional, da Faculdade de Comunicação, Universidade de Brasília, como requisito parcial para obtenção do grau de Bacharela em Comunicação Social.
\end{abstract}

Brasília-DF

Junho de 2017 


\section{FELÍCIA FERNANDES MACEDO}

Guia de Boas Práticas de Comunicação

para Lojas Colaborativas

Memorial Descritivo do Trabalho de Conclusão de Curso apresentado ao curso de Comunicação Organizacional, da Faculdade de Comunicação, Universidade de Brasília, como requisito parcial para obtenção do grau de Bacharela em Comunicação Social. Aprovado pela Banca Examinadora em junho de 2017.

Profa. Dra. Delcia Maria de Mattos Vidal Orientadora - FAC/UnB

Profa. Dra. Elen Cristina Geraldes (Examinadora)

Profa. Dra. Liziane Soares Guazina (Examinadora)

Suplente: Prof. Dr. João José Azevedo Curvello (Suplente) 
Dedico este trabalho às grandes inspirações da minha vida: minha mãe, Regina Coelly, e meu pai, Moacir. 


\section{AGRADECIMENTOS}

Primeiramente, gostaria de agradecer aos meus pais, Regina e Moacir, por sempre estarem ao meu lado, por me transmitirem ideais e virtudes admiráveis e incentivarem para que eu desse o melhor de mim em tudo. O apoio, o amor e a confiança de vocês foram fundamentais para eu chegar até aqui e concluir essa graduação com a certeza de que me tornei uma pessoa muito melhor. Muito obrigada por tudo!

Ao meu namorado, Vítor, melhor amigo e parceiro de todas as horas, pelo amor, pelo carinho, pela companhia, pela paciência, pelo apoio e por sonhar comigo todos os dias.

A toda a minha família, em especial à minha tia Rita, que desde a minha infância sempre disse que eu amaria cursar Comunicação. Ela acertou, e hoje tenho muito orgulho e amor pela profissão que escolhi.

Aos professores da Faculdade de Comunicação e à Universidade de Brasília por todo o conhecimento compartilhado e por todas as contribuições que me deram profissional e pessoalmente. Ao longo desses anos em que cursei uma faculdade em uma universidade pública federal, pude perceber a importância do meu papel como cidadã e promotora de mudanças. O meu olhar sobre o outro mudou e, por isso, posso dizer que concluo minha graduação mais humana, mais consciente, mais empática e com mais vontade de promover transformações no mundo. Com vocês, professores, eu aprendi que a melhor maneira de fazer isso é com a comunicação.

Quero fazer um agradecimento especial à minha orientadora, Delcia Vidal, que abraçou e se envolveu neste trabalho, desde sua concepção até a finalização, com carinho, dedicação e confiança.

Aos meus amigos da turma de comunicação organizacional pelos anos de parceria, convivência, descobertas, muito trabalho e aprendizado. Tenho certeza que teremos muito sucesso.

Às lojas colaborativas Endossa e Mercearia, que fizeram parte da trajetória de produção deste trabalho.

Muito Obrigada! 


\section{RESUMO}

Este trabalho apresenta a formulação do Guia de Boas Práticas de Comunicação para Lojas Colaborativas, um material que atua como fonte de informação e orientação sobre técnicas, estratégias, procedimentos e ações de comunicação para gestores de lojas colaborativas que estão tendo um contato inicial com a comunicação. Considerando as particularidades desses empreendimentos, o Guia apresenta, por meio de uma linguagem objetiva e simples, soluções pensadas para facilitar o planejamento, a gestão e a execução das ações de comunicação. O embasamento teórico englobou as áreas da Comunicação Organizacional, da Economia Criativa e do Consumo colaborativo. Com base em uma abordagem qualitativa e buscando maior aproximação com o objeto de estudo, foram realizadas entrevistas com os sócio-gestores das lojas colaborativas brasilienses Endossa e Mercearia. Com este Guia, espera-se ajudar as lojas colaborativas na compreensão do papel transformador e integrador da comunicação e que se desenvolva uma cultura de comunicação integrada nesses empreendimentos, orientada pelos caminhos do planejamento e guiada pelo relacionamento, de modo que se potencialize a inovação, característica do mercado criativo e colaborativo.

Palavras-chave: Comunicação. Comunicação Organizacional. Consumo colaborativo. Lojas colaborativas. Economia Criativa. Guia. 


\section{LISTA DE FIGURAS}

FIGURA 1. Fachada da Endossa - Loja Colaborativa - Unidade da CLS 306.................. 10

FIGURA 2. Caixinhas da Endossa - Loja Colaborativa.................................................... 11

FIGURA 3. Caixinhas da Endossa - Loja Colaborativa................................................... 11

FIGURA 4. Nichos de exposição da Mercearia - Loja Colaborativa.................................... 12

FIGURA 5. Nichos de exposição da Mercearia - Loja Colaborativa............................... 12

FIGURA 6. Interior da Mercearia - Loja Colaborativa.................................................... 13 


\section{SUMÁRIO}

1 CONTEXTO E PROBLEMA DE PESQUISA................................. 9

1.1 A ideia..................................................................... 9

$1.2 \mathrm{O}$ produto.................................................................... 14

$1.3 \mathrm{O}$ problema de pesquisa...................................................... 14

2 JUSTIFICATIVA........................................................... 15

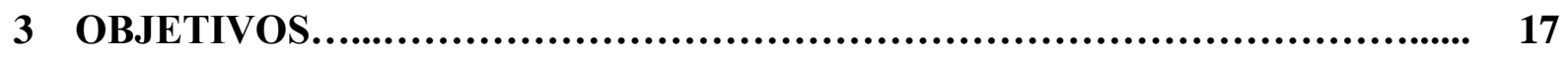

3.1 Objetivo geral.................................................................... 17

3.2 Objetivos específicos.......................................................... 17

4 REFERENCIAL TEÓRICO....................................................... 18

4.1 Fundamentos da Comunicação Organizacional................................... 18

4.2 A Economia Criativa no Brasil................................................ 22

4.3 Consumo colaborativo...................................................... 24

5 METODOLOGIA................................................................. 26

$5.1 \mathrm{O}$ memorial................................................................ $\quad 26$

5.2 Metodologia de pesquisa e coleta do conteúdo para o Guia........................... 26

5.3 A identidade visual do Guia.................................................... 29

5.4 Avaliação do conteúdo........................................................ 31

5.5 Distribuiçãa do Guia.......................................................... 31

6 CONSIDERAÇÕES FINAIS................................................ 33

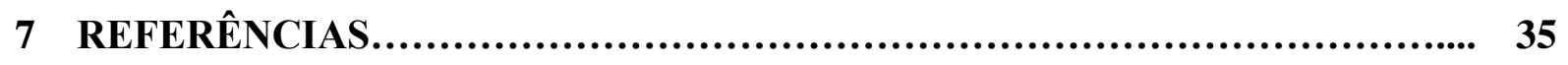

8 APÊNDICE A - ROTEIRO DAS ENTREVISTAS......................................... 39 


\section{CONTEXTO E PROBLEMA DE PESQUISA}

\subsection{A ideia}

Uma intensa vivência cultural e um novo olhar sobre estilo de vida contemporâneo deram o pontapé inicial para a pesquisa sobre a Economia Criativa e o mercado colaborativo. As alternativas propostas por essas novas formas de produção, comercialização de bens e comunicação despertaram meu interesse em compreender os processos de colaboração e seu impacto nessas organizações. A partir dessa mudança de visão pessoal e profissional, surge a necessidade de instruir empreendedores criativos sobre a gestão da comunicação para fins colaborativos, participativos e identitários com uma abordagem organizacional.

A Economia Criativa, como o conceito deixa transparecer, é aquela que está baseada em um alto grau de inovação e de mudança de paradigmas econômicos em sua formatação, mostrando-se como um setor em amplo crescimento no Brasil (SAMPAIO, 2015). O termo Economia Criativa engloba valores econômicos e valores culturais, além de participar da promoção e do desenvolvimento de novos modelos de gestão e novas formas de trabalho, consumo e estilo de vida (OLIVEIRA et al., 2013).

O ciclo criativo - criação, produção e distribuição - está pautado em três elementoschave: conhecimento, criatividade e capital intelectual de pessoas ou grupos e visam à geração de riqueza, ao impacto social e à diversidade. A Economia Criativa cria novos desafios para a Comunicação Organizacional, afinal é um setor que abrange 14 segmentos, sendo eles: Arquitetura e Urbanismo; Artesanato; Artes Cênicas; Artes e Antiguidades; Audiovisual; Design; Editoração; Fotografia; Gastronomia; Moda; Música; Publicidade; Software; e Rádio e Televisão (OLIVEIRA et al., 2013).

A Economia Criativa está diretamente relacionada ao Consumo colaborativo. Desde a crise econômica de 2008, essa nova percepção sobre novas formas de consumir de uma maneira mais econômica, colaborativa ou sustentável vem se espalhando pelo mundo. Esse pensamento está estimulando novas formas de agir, trabalhar, empreender e gerir. O mercado criativo e colaborativo brasileiro vem acompanhando esse movimento. Hoje, já é comum ver matérias de diversos veículos de comunicação sobre lojas colaborativas, espaços de coworking, grupos de trocas e iniciativas de ocupação do espaço público de maneira criativa. Provavelmente você ou algum conhecido já foi ou ouviu falar desse tipo de empreendimento.

Nesse cenário, as lojas colaborativas surgem oferecendo espaço a pequenos empreendedores, que geralmente ficam à margem do mercado varejista, permitindo que qualquer pessoa possa alugar um espaço e vender seus produtos. Além de os produtos 
estarem em constante renovação graças às novas ideias dos produtos e à rotatividade, as lojas colaborativas ainda apresentam soluções tais como a divisão de custos de manutenção de uma loja e a multiplicação do alcance da divulgação. A pioneira desse movimento no Brasil é a Endossa Loja Colaborativa. Em 2008, a primeira loja foi fundada na Rua Augusta em São Paulo. Atualmente, a Endossa está presente em dois estados brasileiros - São Paulo e Paraná - e no Distrito Federal, totalizando seis lojas.

Por meio das mãos de Maíra Belo, Luana Ponto e Victor Parucker, a Endossa - que possui formato de franquia - chegou a Brasília em 2014, na CLS 307. Hoje, a Endossa mudou-se para uma loja maior na CLS 306 e abriu uma segunda filial na CLN 310. Ela representa um novo modelo de comércio criativo, baseado em conceitos das redes sociais. $\mathrm{O}$ mix de produtos depende de um mecanismo de filtragem baseado na colaboratividade: o consumidor final participa do processo de curadoria quando realiza uma compra e "endossa" a permanência daquele expositor.

O slogan da Endossa Brasília é "uma loja feita por quem compra e por quem faz". Por concentrar diversos expositores no mesmo lugar, a Endossa atua como um catalisador de vendedores e clientes, facilitando as transações em um ambiente descontraído e em localizações privilegiadas. A filtragem colaborativa é o mecanismo utilizado para envolver o consumidor e suas demandas, baseada na sua própria percepção de qualidade dos produtos.

FIGURA 1. Fachada da Endossa - Loja Colaborativa - Unidade da CLS 306

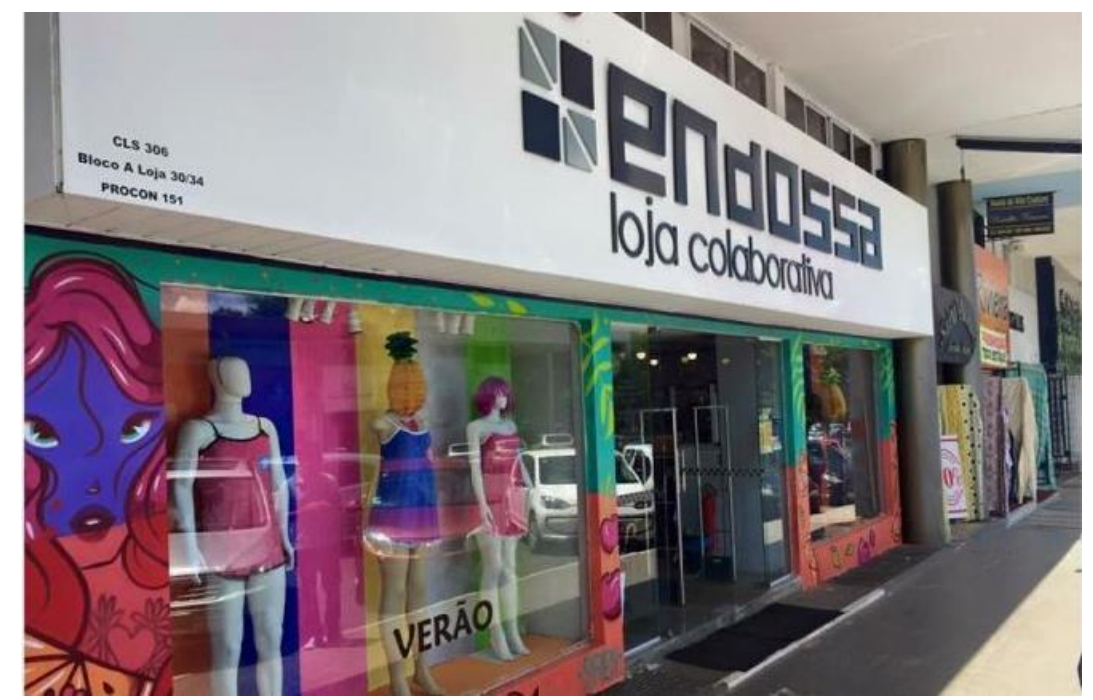

Fonte: Reprodução, Paula Santana/GPS Brasília, 2016. 
FIGURA 2. Caixinhas da Endossa - Loja Colaborativa

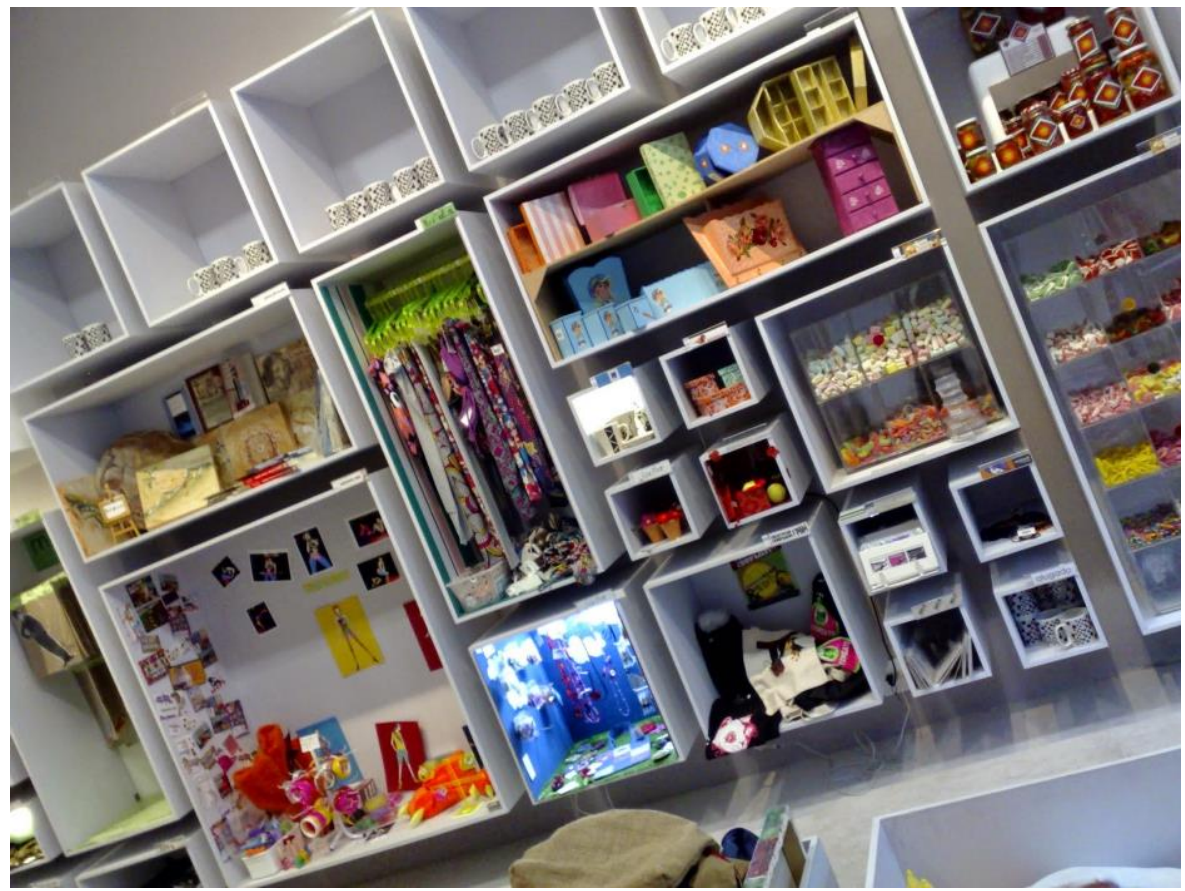

Fonte: Thaís Pedrada, 2014.

FIGURA 3. Caixinhas da Endossa - Loja Colaborativa

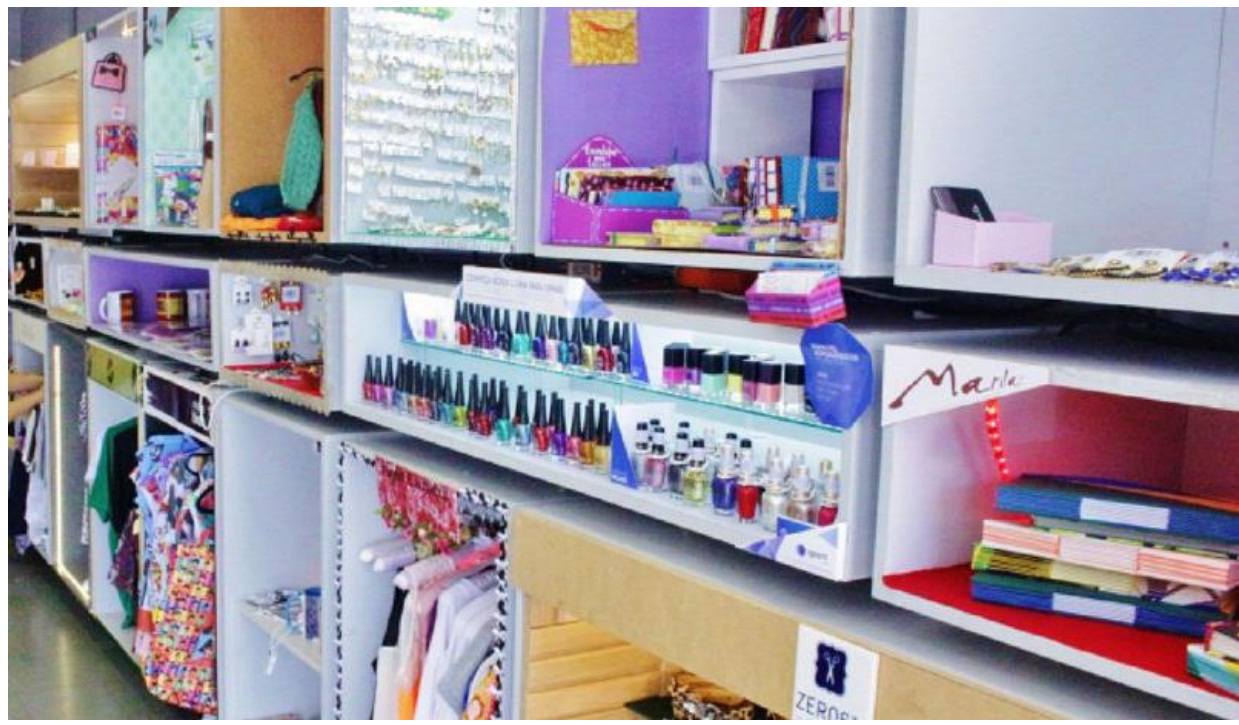

Fonte: Site Minhocco

Em um primeiro contato com os sócios-gestores da Endossa, a ideia da criação de um produto de comunicação que atendesse às necessidades do mercado colaborativo - no que tange à gestão da comunicação - se revelou como um caminho prático e direto de contribuição para o fortalecimento desse segmento. Para tornar essa ideia realidade, era importante conhecer outras referências e outros segmentos de lojas colaborativas. 
A Mercearia é uma loja colaborativa da área da Gastronomia localizada na CLN 412. Aberta em julho de 2016, lá é possível encontrar vinhos, pães, molhos, cafés, cervejas, doces, bolos, tortas, congelados e chás de produtores locais. Os proprietários, Carol Mullets, André Batista e Gustavo Bills, encontraram uns nos outros o complemento para um negócio neste ramo. Carol é publicitária, André é chef de cozinha e Gustavo é produtor de eventos e fundador de um grupo colaborativo no Facebook, o Boomerang.

FIGURA 4. Nichos de exposição da Mercearia - Loja Colaborativa

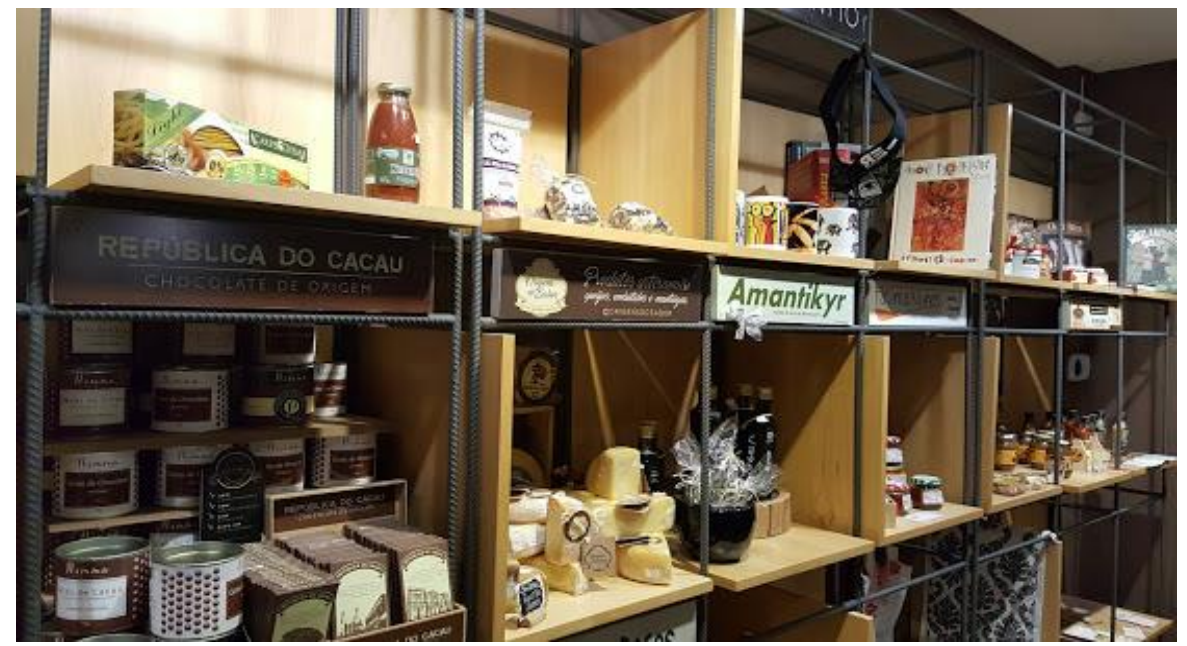

Fonte: Raquel Pellicano, site Mercearia Colaborativa no Business Google.

FIGURA 5. Nichos expositores na Mercearia - Loja Colaborativa

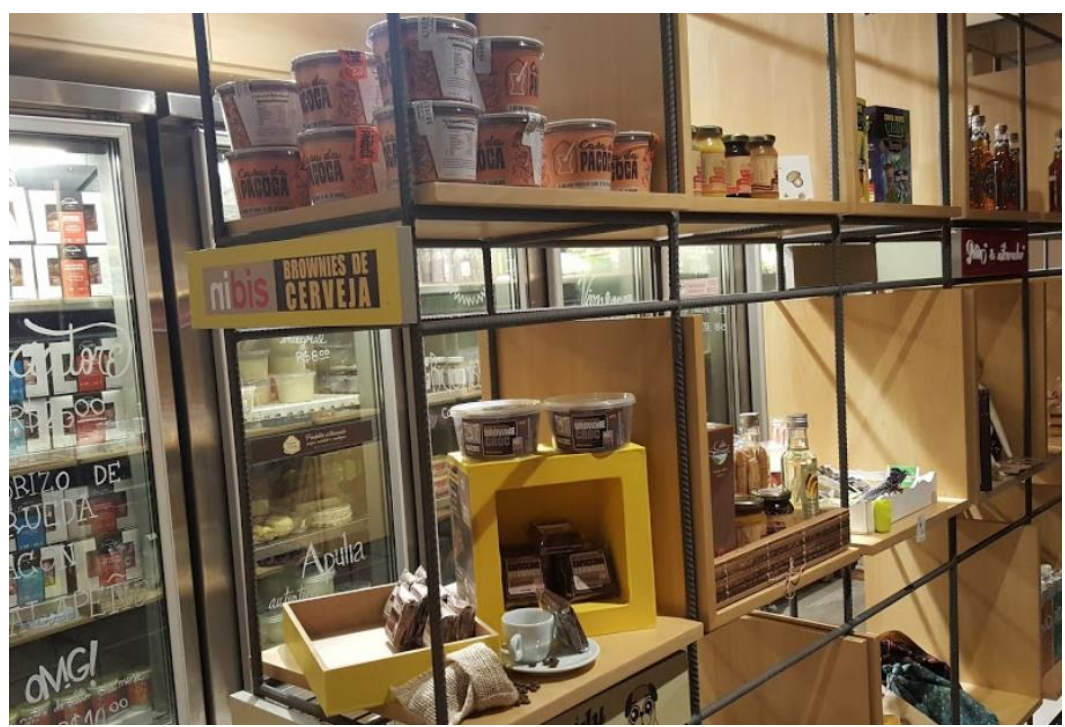

Fonte: Raquel Pellicano, site Mercearia Colaborativa no Business Google. 
A Mercearia também trabalha com aluguel de espaços para vendas. Existem três modelos de expositores: novos empreendedores, fornecedores de restaurantes e fornecedores de ponto de venda. Para cada um deles, é especificado um perfil, como, por exemplo, para as novas marcas, de pequenos produtores, as vantagens de alugar um espaço na Mercearia são o ponto fixo, o teste e o feedback dos produtos e divulgação da marca. Para os fornecedores, as vantagens são o aumento das vendas, a inserção em um novo cenário, a valorização do produto e a facilidade na logística de venda.

FIGURA 6. Interior da Mercearia - Loja Colaborativa

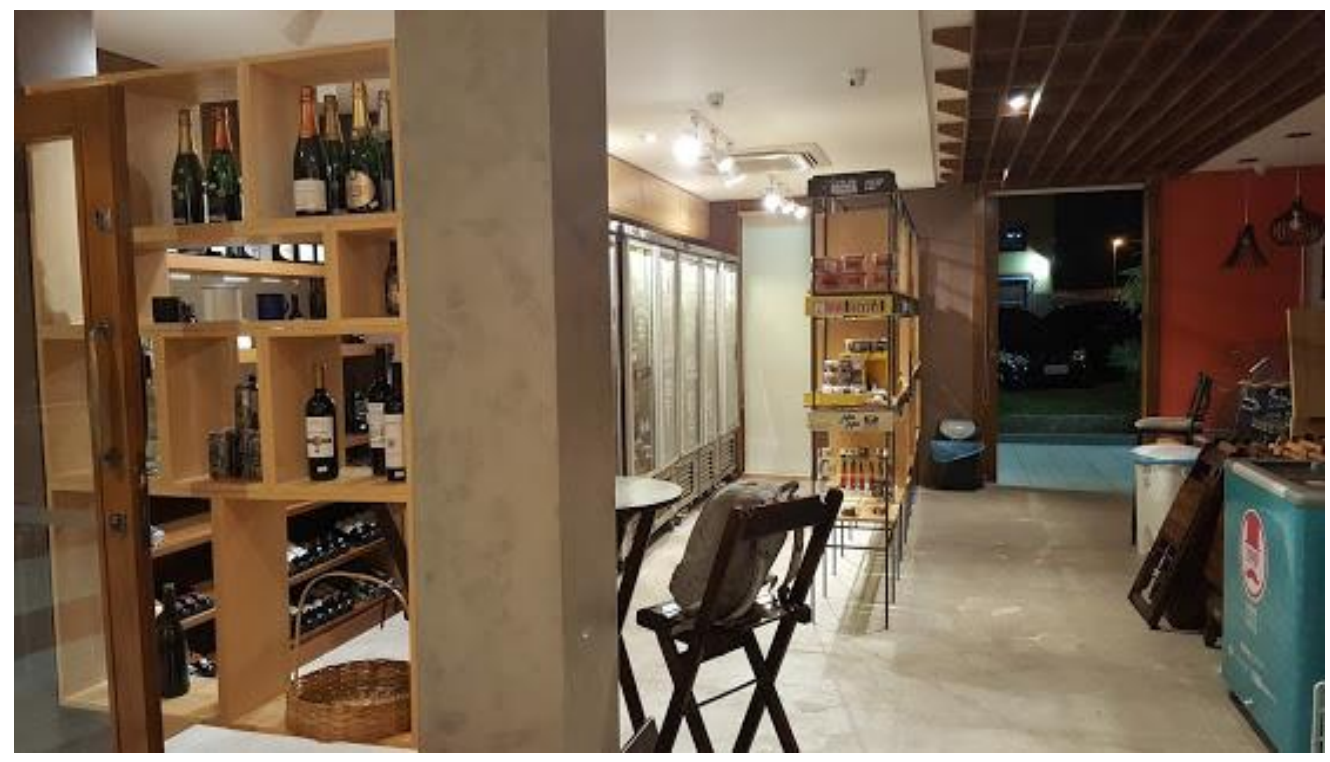

Fonte: Raquel Pellicano, site Mercearia Colaborativa no Business Google.

Tomando como base realidades de lojas colaborativas ao mesmo tempo distintas e parecidas, a ideia de desenvolver um guia de comunicação que não abarcasse somente determinado tipo de loja colaborativa pareceu muito boa. Nesse ponto, era imprescindível que a construção do Guia também envolvesse processos colaborativos. Isso só foi possível graças à participação e à colaboração dos representantes das lojas colaborativas citadas acima. Dessa maneira, o Guia seria um instrumento capaz de contribuir com esse tipo de empreendimento de uma maneira mais abrangente, envolvendo a colaboratividade e a cooperação desde a concepção até a distribuição. 


\section{$1.2 \mathrm{O}$ produto}

O Guia de Boas Práticas de Comunicação para Lojas Colaborativas é um produto voltado para os gestores de lojas colaborativas e tem como principal objetivo auxiliar no processo de gestão da comunicação, podendo ser utilizado para fins de comunicação institucional e mercadológica.

Como sua principal característica, o produto aponta a comunicação como instrumento imprescindível para a construção de uma identidade organizacional. O conteúdo do Guia traz exemplos de práticas, diretrizes e estratégias de comunicação que poderão ser aplicadas em diferentes lojas colaborativas.

O Guia contribui para a instrução de gestores, de forma que estes desenvolvam ações de comunicação abrangentes e inovadoras. Além de ensinar a utilização das boas práticas de comunicação, o produto fornece informações que demonstram como a comunicação é capaz de criar relacionamentos estreitos entre a organização e seus públicos.

\subsection{0 problema de pesquisa}

O ponto de partida para a definição do problema de pesquisa surge a partir de uma conversa com os sócios-gestores da Endossa Loja Colaborativa sobre a ideia de realizar o Trabalho de Conclusão de Curso (TCC) nessa organização. Partindo do pioneirismo da Endossa no segmento de lojas colaborativas e das dificuldades mencionadas em relação à gestão da comunicação, surge esse desejo de desenvolver um trabalho que possa auxiliar diversas lojas colaborativas em termos de práticas de comunicação.

Assim, inúmeros questionamentos surgem nesse sentido: Como as lojas colaborativas gerenciam sua comunicação lidando com tantos stakeholders (clientes, expositores, parceiros, funcionários, etc.)? Quais práticas de comunicação podem contribuir para melhorar esse processo? De que maneira esses procedimentos podem ser apresentados?

Como resposta a essas perguntas, o desenvolvimento de um guia de Comunicação abordado neste trabalho por meio de processos institucionais e mercadológicos - para lojas colaborativas mostra-se como uma solução exequível e aplicável, que pode contribuir para a formação e a atuação dos gestores em aspectos relacionados à gestão da comunicação de seus empreendimentos. 


\section{JUSTIFICATIVA}

A principal razão para a produção de um guia de comunicação para lojas colaborativas é poder contribuir diretamente para mudanças nas práticas gerenciais que envolvem a comunicação, a construção da identidade organizacional e o relacionamento com públicos-alvo.

Ao longo do curso, os instrumentos de comunicação, o planejamento, a gestão e uma comunicação propositiva, capaz de promover o sucesso organizacional, sempre estiveram em meu rol de interesses. Uma mudança de percepção em relação às novas formas de consumo despertou a curiosidade e o interesse de pesquisar sobre a colaboratividade e seu impacto na comunicação, no consumo e no ambiente social.

A Economia Criativa é um mercado em crescimento no Brasil e no mundo. Incluídas neste movimento, as lojas colaborativas começam a surgir como uma alternativa às grandes corporações, buscando a valorização do produtor local, o crescimento do mercado regional, o desenvolvimento de um novo estilo de vida e participação do público no processo de curadoria. Todos esses elementos demonstram como a comunicação nesse tipo de organização pode ser complexa. Toda essa complexidade leva a pensar sobre a falta de materiais direcionados para lojas colaborativas e resulta na proposta de criação do Guia descrito neste trabalho. O Guia de Boas Práticas de Comunicação para Lojas Colaborativas é um produto inédito por abordar a comunicação em processos colaborativos sob a ótica das práticas de comunicação institucional e mercadológica.

As lojas colaborativas ainda podem ser consideradas novos modelos de negócio no Brasil. Dessa forma, não é fácil encontrar informações específicas e de fácil entendimento sobre o gerenciamento da comunicação para essa nova forma de trabalho e gestão por ser um movimento econômico recente. É preciso também levar em consideração que muitas lojas colaborativas ainda não possuem uma equipe especializada em comunicação, como é o caso da Endossa e da Mercearia.

Este trabalho possui relevância para a área acadêmica da Comunicação por apresentar novos aspectos sobre a comunicação em espaços colaborativos e ser mais um produto pensado para o âmbito organizacional. O Guia contribui para a elaboração de planos, estratégias e ações de comunicação nesses novos espaços de trabalho e gestão. Além disso, a intenção deste Guia é promover o desenvolvimento e o fortalecimento do mercado colaborativo e reforçar a importância da Comunicação Organizacional. 
Assim, este Guia foi desenvolvido para atender às demandas que as lojas colaborativas brasileiras têm no sentido de encontrar os melhores instrumentos para exercer a gestão da comunicação e favorecer a criação e o estreitamento dos relacionamentos entre a organização e seus públicos, interna e externamente. Além disso, a distribuição deste produto - pensado para atuar como instrumento colaborativo - também foi pensada envolvendo processos colaborativos e de redes sociais. Sendo assim, ele foi disponibilizado na plataforma Issuu, uma espécie de banca de revistas e livraria digital onde é possível ler livros e revistas gratuitamente, além de poder fazer download, curtir, salvar e compartilhar esses conteúdos. 


\section{OBJETIVOS}

\subsection{Objetivo geral}

Produzir um guia que contribua para as boas práticas de comunicação em lojas colaborativas.

\subsection{Objetivos específicos}

- Apresentar procedimentos de comunicação, por meio do desenvolvimento de um guia, que atendam às particularidades das lojas colaborativas, com uma linguagem clara, objetiva e simples, pensada para pessoas que estão vivenciando um contato inicial com a comunicação.

- Conhecer os processos de comunicação das lojas colaborativas brasilienses Endossa e Mercearia com base em entrevistas.

- Desenvolver um Guia de Boas Práticas de Comunicação de fácil compreensão e aplicação que atue como fonte de informação e orientação na gestão da comunicação.

- Criar um produto com uma estética visual atraente e que se relacione com a temática do Guia. 


\section{REFERENCIAL TEÓRICO}

\subsection{Fundamentos da Comunicação Organizacional}

A Comunicação Organizacional traz um olhar próprio para os fenômenos da comunicação no âmbito das organizações. O objeto de estudo da Comunicação Organizacional está relacionado à forma como os processos comunicacionais e interacionais acontecem em uma instituição. Margarida Kunsch (2003, p. 149) define Comunicação Organizacional como "a disciplina que estuda como se processa o fenômeno comunicacional dentro das organizações no âmbito da sociedade global. Ela analisa o sistema, o funcionamento e o processo de comunicação entre a organização e seus diversos públicos”.

Compreender a evolução da estrutura, das modalidades e do conceito de organizações para além do âmbito empresarial é fundamental para perceber a importância da comunicação nesses novos espaços, resultado do processo de globalização. Nesse sentido, cabe aqui trazer a definição de organizações sob a ótica de Paulo Nassar (2009, p. 62), de modo que seja possível enxergar associações, escolas, clubes, empresas, comunidades, entre outros ambientes de convívio social como diferentes tipos de organizações:

\footnotetext{
Podemos, assim, definir uma organização como um sistema social e histórico, formal, que obrigatoriamente se comunica e se relaciona, de forma endógena, com seus integrantes e, de forma exógena, com outros sistemas sociais e com a sociedade. E organizações são estruturadas com pessoas que atuam segundo divisões e processos de trabalho, dependem de recursos de toda ordem, dentre os quais destacamos os materiais, financeiros, mercadológicos, científicos tecnológicos, históricos (gestão do conhecimento e da memória), comunicacionais e relacionais.
}

A comunicação apresenta-se como uma atividade que envolve riscos e oportunidades. A expansão dos meios digitais de comunicação gerou novas formas de produção de diálogo e relacionamento com os mais diversos públicos espalhados pelo mundo. De maneira momentânea ou duradoura, várias partes se envolvem com as organizações, e seu sucesso depende do modo como a relação com tais partes interessadas é desenvolvida. O termo stakeholder, desenvolvido pelo filósofo Robert Edward Freeman (1984), denomina essas partes, sem as quais a organização não sobreviveria. Podem ser acionistas, investidores, funcionários, fornecedores, clientes, ONGs, profissionais de imprensa, entre outros.

Para Mikhail Bakhtin (apud ROMAN, 2009, p. 128), a comunicação é um processo dialógico de estabelecimento de relações e não apenas transmissão de informação. Nas organizações, a comunicação é usada de diversas maneiras. Nesses espaços, desenvolvem-se técnicas, instrumentos, normas, etc. E, simultaneamente, ocorrem situações de expressão de 
capacidades, habilidades, comportamentos e postura dos integrantes da organização. Segundo Gaudêncio Torquato do Rego (2009, p. 13), essa comunicação expressiva é o que humaniza, suaviza, diverte, agrada, impacta e sensibiliza:

\footnotetext{
Quando o teor das comunicações instrumentais é muito denso, as organizações se transformam em ambientes ásperos e áridos. De outra forma, quando as comunicações expressivas se expandem nos fluxos da informalidade, as organizações dão vazão a climas alegres, cordiais, solidários, humanizados.
}

Rego (1986, p. 9) acredita que a "comunicação exerce um extraordinário poder para o equilíbrio, o desenvolvimento e a expansão das empresas". Nessa perspectiva, Luiz Carlos Iasbeck (2009) complementa que a comunicação passou a exercer um papel estratégico e, no ambiente fortemente competitivo da atualidade, já não é mais possível negligenciar a comunicação ou mantê-la longe dos responsáveis pela gestão estratégica das organizações. $\mathrm{O}$ conceito de Comunicação Organizacional - que vem sendo amplamente estudado e trabalhado por Kunsch, pioneiramente em seus estudos e publicações - engloba a integração da organização com base na comunicação. Para a autora, a Comunicação Organizacional é composta pelas modalidades Comunicação administrativa, Comunicação interna, Comunicação institucional e Comunicação mercadológica.

\section{Comunicação administrativa}

Administrar uma organização exige planejamento, coordenação, direção, controle de recursos, entre outros instrumentos de gestão, de modo que se alcancem os objetivos organizacionais. Isso sugere um contínuo processo de comunicação. A comunicação administrativa é "aquela que se processa dentro da organização, no âmbito das funções administrativas; é a que permite viabilizar todo sistema organizacional, por meio de uma confluência de fluxos e redes" (KUNSCH, 2003, p. 152).

A comunicação administrativa está relacionada a toda comunicação que permite o funcionamento do sistema organizacional, seja por meio de redes formais ou informais. Alguns instrumentos desse tipo de comunicação podem ser exemplificados como manuais de conduta, normas, ofícios, memorandos, entre outros. 


\section{Comunicação interna}

A comunicação interna, segundo Kunsch (2003 p. 154), é uma ferramenta estratégica que viabiliza a interação entre a organização e seus empregados a fim de compatibilizar os interesses dos funcionários e da instituição por meio de canais de diálogo, troca de informações e experiências em todos os níveis hierárquicos. Rego (1986, p. 121) complementa tal pensamento ao propor que os canais e os instrumentos de comunicação interna (tais como as publicações internas) são aqueles que transmitem as informações oficiais, alguns dos valores organizacionais e são capazes de produzir um clima coletivo harmônico.

A comunicação interna, portanto, é uma parte do processo de comunicação organizacional destinada ao público interno da organização a fim de alavancar a sensação de pertencimento nos funcionários, diminuir efeitos de crise interna, evitar ruídos de comunicação e oferecer troca de informações. Um dos desafios da comunicação interna é garantir que a linguagem dos instrumentos de comunicação (como e-mails institucionais, murais, informativos, intranet, etc.) estejam alinhados com as especificidades do público interno, como nível de escolaridade, faixa etária e gênero. Também não se pode deixar de lado a importância de se transmitir a missão, a visão e os valores da organização nesses canais (KUNSCH, 2003).

\section{Comunicação institucional}

A comunicação institucional é a área da comunicação organizacional destinada a desenvolver a identidade e a personalidade da organização perante seus públicos, de modo que esta se mantenha simpática, credível, confiante e confiável perante o mercado, com o intuito de relacionar-se politicamente e socialmente. Ela é responsável por repassar ao público-alvo o valor, a missão, a visão e a filosofia da organização de forma compreensível. O exercício da comunicação institucional exige um conhecimento profundo a respeito dos atributos da instituição, pois, conforme a percepção de Margarida Kunsch (2003, p. 164), “a comunicação institucional é a responsável direta, por meio da gestão estratégica das relações públicas, pela construção e formatação de uma imagem e identidade corporativas fortes e positivas de uma organização". Esta comunicação pretende definir o papel da organização e sua razão de existir, tanto interna quanto externamente.

De acordo com Gaudêncio Torquato do Rego (1985 apud KUNSCH, 2003, p. 164), para atingir seu objetivo, a comunicação institucional utiliza “estratégias de relações públicas, tanto no campo empresarial, como no governamental, de imprensa, publicidade, até técnicas e 
práticas de lobby". Também são consideradas ferramentas de comunicação institucional o jornalismo empresarial, a assessoria de imprensa, o marketing social, o marketing cultural, a imagem e a identidade corporativa e a editoração multimídia (KUNSCH, 2003, p. 166).

\section{Comunicação mercadológica}

A comunicação mercadológica é aquela que contempla toda a produção comunicativa que gira em torno dos objetivos de divulgação publicitária dos produtos e serviços de uma empresa. Está diretamente relacionada ao marketing.

Margarida Kunsch (2003) afirma que essa área da comunicação organizacional integrada é responsável por definir todas as ferramentas que compõem o mix de comunicação de marketing, tais como a propaganda e a promoção de vendas, ferramentas estas que devem ser assertivas e abastecidas com dados advindos de pesquisas de mercado e de produto. A autora complementa que durante o processo de gerenciamento da comunicação mercadológica o mix de comunicação deve ser utilizado conforme convém em cada caso e propósito. Sua atividade central é a divulgação de informações, ideias, conceitos, produtos e serviços para os públicos de interesse fora da empresa com o objetivo de experimentação e vendas, além de fortalecer a imagem da organização. Para tanto, são realizados trabalhos de relacionamento com a mídia, campanhas de publicidade e atendimento a clientes.

Durante muito tempo, as ferramentas de comunicação mercadológica limitaram-se à propaganda, à promoção de vendas, merchandising, feiras e exposições, marketing direto, vendas pessoais, etc. Hoje, há uma gama muito maior de ferramentas de divulgação disponibilizadas graças à internet e ao crescimento das mídias sociais. Eis um dos principais fatores que evidencia a necessidade da comunicação participar das ações estratégicas: o intermédio das relações com o público alvo.

Segundo Kunsch (2003, p. 164), a comunicação mercadológica está encarregada de "todas as manifestações simbólicas de um mix integrado de instrumentos de comunicação persuasiva para conquistar o consumidor e os públicos-alvo estabelecidos pela área de marketing". 


\subsection{A Economia Criativa no Brasil}

A criatividade é inerente à condição humana. E a criatividade aliada a conhecimento técnico, quando utilizados como recursos produtivos, geram bens e serviços diferenciados e capazes de criar significados, oferecer experiências, despertar emoções e gerar desejos. Essa diferenciação aumenta a competitividade da indústria e fideliza clientes, cada vez mais ávidos por desfrutar novas experiências e mais exigentes de sua qualidade de vida (FIRJAN, 2016, p. 4).

O conceito de Economia Criativa ainda está em evolução. Desde os anos 2000, esse termo vem ganhando cada vez mais expressão e relevância nos meios empresarial, acadêmico e social. Há poucas dúvidas sobre o que envolve a Economia Criativa, Howkins (apud OLIVEIRA et al., 2013) estabelece a ideia de que a Economia Criativa se sustenta na relação entre a criatividade, o simbólico e a economia. Com base em sua atuação, define-se que:

Economia criativa é o conjunto de atividades econômicas que dependem do conteúdo simbólico - nele incluído a criatividade como fator mais expressivo para a produção de bens e serviços, guardando estreita relação com aspectos econômicos, culturais e sociais que interagem com a tecnologia e propriedade intelectual. (OLIVEIRA et al., 2013, p.7)

A criatividade tornou-se um diferencial competitivo entre as empresas e as economias mundiais. Considerado um setor que se manteve imune às grandes crises econômicas globais

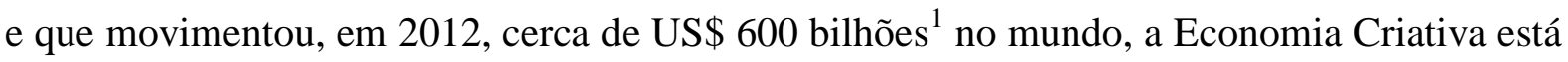
em expansão. Os investimentos na capacitação e no estímulo ao desenvolvimento da inteligência criativa do indivíduo são cada vez maiores, inclusive no Brasil, que há alguns anos apresentou um grande plano para dobrar os investimentos e aumentou a oferta de financiamento para o setor. O BNDES respondeu por R \$ 3,18 bilhões em desembolsos para a economia criativa entre 1997 e 2014 (CAVALCANTI, 2016).

Segundo o Panorama da Economia Criativa no Brasil, publicada pelo Instituto de Pesquisa Econômica Aplicada (Ipea) em 2013, “estima-se que a economia criativa formal represente entre $1,2 \%$ e $2 \%$ do Produto Interno Bruto (PIB) brasileiro e aproximadamente $2 \%$ da mão de obra e 2,5\% da massa salarial formal. Além disso, os trabalhadores em economia criativa ganham mais e são mais escolarizados que a média" (OLIVEIRA et al., 2013, Sinopse).

A Federação das Indústrias do Rio de Janeiro (FIRJAN) possui dados ainda mais recentes - levantados pelo Mapeamento da Economia Criativa no Brasil de 2016 - que reiteram o potencial econômico do setor e ilustram seu crescimento: “a participação do PIB

\footnotetext{
1 Disponível em: <http://www.otempo.com.br/capa/economia/brasil-quer-dobrar-investimento-em-economiacriativa-1.335524>. Acesso em: 10 jan. 2017.
} 
criativo estimado no PIB brasileiro cresceu de 2,56\% para 2,64\%. Como resultado, a área criativa gerou uma riqueza de $\mathrm{R} \$ 155,6$ bilhões para a economia brasileira no último ano, valor equivalente à soma dos valores de mercado das marcas Facebook, Zara e L'Oréal reunidas" $(2016$, p. 6).

Conforme a FIRJAN, em 2013, 251 mil empresas formavam a indústria criativa no Brasil. Em comparação com 2004, houve um crescimento de 69,1\%, quando eram 148 mil. O levantamento do Ipea estima que a economia criativa empregou cerca de 580 mil trabalhadores formais em 2010.

Como visto anteriormente, a Economia Criativa é um conjunto de segmentos dinâmicos que engloba valores econômicos e valores culturais, além de participar da promoção e do desenvolvimento de novos modelos de gestão e novas formas de trabalho, consumo e estilo de vida. Consoante ao panorama apresentado pelo Ipea, pode-se afirmar que iniciativas da Economia Criativa são capazes de promover a diversificação, seja econômica, seja de comércio e inovação, e estão diretamente relacionadas às novas tecnologias, principalmente no que tange ao setor de informação e comunicação. Esse cenário pode ser ilustrado com base nos dados demográficos trazidos pela FIRJAN em 2016.

Segundo as informações da FIRJAN, no período 2013-2015, ocorreram mudanças significativas no segmento de profissionais que atuam na economia criativa. Os dados indicam uma grande participação de profisssionais das áreas de comunicação em atividades como publicação e mídia impressa, new media, serviços criativos, audiovisual e design. Há também uma maior especialização e profissionalização e maior foco na experiência do consumidor (agregação de valor para atendimento eficiente ao consumidor). Tendências observadas, sobretudo, nos segmentos de Design, Moda, Publicidade e Expressões Culturais.

Observando esse cenário de destaque da comunicação intrínseco à Economia Criativa, a pesquisadora Leila Gasparindo, especialista em Gestão de Comunicação Organizacional e Relações Públicas pela ECA/USP, explicita como a comunicação é capaz de ajudar a desenvolver e fortalecer uma cultura da inovação em organizações, regiões e países. Ela afirma que todo o processo de inovação deve ser apoiado por estratégias comunicacionais que estimulem a reflexão.

As estratégias de comunicação organizacional baseiam-se no diálogo aberto para a identificação de formas de estímulo ao surgimento de novas ideias ou tecnologias e no apoio aos processos de mudança transformadora, funcionando como um sistema que busca adaptação, fabrica atenção e respeita a complexidade e a identidade cultural (GASPARINDO, 2016, p 345). 
Gasparindo ainda reitera o papel estratégico da comunicação nas organizações, principalmente naquelas que buscam atuar nos princípios da Economia Criativa. Segundo a autora, a estratégia competitiva e o planejamento da organização devem levar em conta quais competências precisam ser desenvolvidas ou reforçadas junto aos colaboradores para alcançar o sucesso organizacional. Essa conexão entre as estratégias e as competências virá, claramente, do uso dos instrumentos de Comunicação Institucional, responsáveis por repassar aos públicos-alvo a missão, a visão, os valores e a filosofia da organização.

\subsection{Consumo colaborativo}

Desde o período pós-Primeira Guerra Mundial, o hiperconsumismo vem sendo encarado como uma forma de alcançar a realização pessoal, demonstrar status, sucesso e poder. Os pioneiros na pesquisa sobre consumo colaborativo, Rachel Botsman e Roo Rogers (2011), elucidam que, ao longo das décadas, o consumo estabeleceu-se como estilo de vida, no qual os rituais de compra e uso de determinados bens está relacionado à satisfação pessoal.

Botsman e Rogers (2011) descrevem como a crise econômica de 2008 provocou uma mudança em certos grupos de consumidores no que diz respeito às suas escolhas de consumo e decisões de compra. A necessidade de acessar bens de forma mais econômica, colaborativa e sustentável desencadeou uma popularização do conceito de consumo colaborativo que vem se expandindo pelo mundo:

Para desenvolver uma ideia de Charles Leadbeater, discutida no seu livro We-Think, no século XX do hiperconsumismo éramos definidos por crédito, pela propaganda e pelas coisas que possuíamos. No século XXI do consumo colaborativo, seremos definidos pela reputação, pela comunidade e por aquilo que podemos acessar, pelo modo como compartilhamos e pelo que doamos (BOTSMAN; ROGERS, 2011, p. 16).

Nos últimos anos, a palavra "colaboração" passou a integrar o vocabulário, o cotidiano de economistas, filósofos, caçadores de tendências, empreendedores e muitos outros entes sociais (BOTSMAN; ROGERS, 2011). O crescimento de iniciativas colaborativas ao redor do mundo é visível. Para citar alguns exemplos que já extrapolaram fronteiras: Airbnb (aluguel de quartos e apartamentos); Zipcar (compartilhamento de carros); Netflix (aluguel de filmes, séries e programas de TV online); lojas colaborativas; espaços de Coworking e nesse rol também entra o compartilhamento de conteúdo, vivenciado tão fortemente nas redes sociais como Facebook, Instagram, Flickr, YouTube, etc. Trazendo essa exemplificação para território brasiliense, o grupo "Boomerang” no Facebook destaca-se por 
sua proposta de ser um espaço de encontro entre pessoas que desejam alugar, emprestar, doar ou trocar bens e serviços.

Rachel Botsman e Roo Rogers caracterizam o consumo colaborativo como o resgate de práticas que historicamente eram bastante comuns na sociedade, como a troca, o compartilhamento, o empréstimo, a locação e a doação, porém agora suportados pela internet, pelas redes sociais e por plataformas mobile. Segundo os autores, essas novas ferramentas viabilizam um encontro mais rápido do objeto desejado e facilitam a "negociação" (BOTSMAN; ROGERS, 2011).

"Consumo colaborativo não tem nada a ver com compartilhamento forçado e educado. Pelo contrário, ele coloca em vigor um sistema em que as pessoas dividem recursos sem perder liberdades pessoais apreciadas e sem sacrificar seu estilo de vida." (BOTSMAN; ROGERS, 2011, p. 19). Para os autores, o consumo colaborativo é um caminho para que as pessoas percebam o benefício do acesso aos produtos em vez de possuí-los. Com isso, elas economizam dinheiro, tempo, espaço, além de terem a chance de fazer novos amigos e se legitimar como cidadãos conscientes e ativos. Com essa dinâmica, o consumo colaborativo possui uma configuração que permite que ele cresça cada vez mais. 


\section{METODOLOGIA}

\subsection{0 memorial}

Para o embasamento teórico deste memorial, foram realizados um levantamento de informações sobre as lojas colaborativas brasilienses Endossa e Mercearia e a leitura de artigos, periódicos acadêmicos, anais de congressos e livros sobre os temas que envolvem o quadro teórico do estudo: comunicação organizacional e economia criativa.

$\mathrm{Na}$ primeira etapa, foi realizada uma revisão bibliográfica sobre a Comunicação Organizacional - institucional, interna, administrativa e mercadológica. Para tanto, foram utilizados livros e artigos de autores renomados no campo da comunicação, como Margarida Kunsch, Gaudêncio Torquato do Rego, Luiz Carlos Iasbeck e Paulo Nassar.

Para a integração desse estudo ao cenário do empreendedorismo criativo no Brasil, foram utilizados dados encontrados em consultas a relatórios de pesquisas realizadas por instituições relevantes, tais como o Instituto de Pesquisa Econômica Aplicada (Ipea) e a Federação das Indústrias do Estado do Rio de Janeiro (FIRJAN). O "Panorama da Economia Criativa no Brasil", produzido pelo Ipea em 2013 e o "Mapeamento da Economia Criativa no Brasil”, produzido pela FIRJAN em 2014 e 2016, apresentam dados como crescimento, número de trabalhadores, participação na economia, entre outros.

Além disso, tornou-se fundamental obter informações sobre a relação existente entre a Comunicação e a Economia Criativa. A principal fonte de pesquisa foram os artigos publicados nos Anais do $10^{-}$Congresso da Associação Brasileira de Pesquisadores de Comunicação Organizacional e Relações Públicas (Abrapcorp), cujo tema era "comunicação, economia criativa e organizações".

\subsection{Metodologia de pesquisa e coleta do conteúdo para o Guia}

O Guia é o resultado de um trabalho de pesquisa acerca da gestão e dos instrumentos de comunicação utilizados pelas lojas colaborativas Endossa e Mercearia para alcançar e criar relacionamentos com seus públicos. Esta pesquisa configura-se uma metodologia indutiva, qualitativa e em nível de pesquisa exploratória. Segundo Gil (2008), o método indutivo caracteriza-se pela observação e pela análise de fatos e fenômenos. A partir disso, identificam-se as relações existentes entre eles e parte-se para a elaboração de um quadro geral. 
Uma pesquisa qualitativa trabalha com variáveis que não permitem inferências estatísticas e pressupõe a análise de dados baseada na capacidade e no estilo do pesquisador (GIL, 2008). Marconi e Lakatos (2003, p. 188) tratam as investigações exploratórias como um tipo de pesquisa que objetiva a "formulação de questões ou de um problema, com tripla finalidade: desenvolver hipóteses, aumentar a familiaridade do pesquisador com um ambiente, fato ou fenômeno, para a realização de uma pesquisa futura mais precisa ou modificar e clarificar conceitos". As autoras complementam que para esse tipo de pesquisa de campo podem ser empregados procedimentos de coleta como entrevista, observação participante ou análise de conteúdo.

A técnica de pesquisa utilizada para a coleta de insumos para o conteúdo do Guia foi a entrevista semiestruturada. A entrevista é um instrumento de pesquisa que é bastante utilizado nos vários campos da ciência. Segundo Marconi e Lakatos, alguns autores consideram a entrevista como uma técnica excelente para obtenção de dados em uma investigação social. A entrevista semiestruturada permite que se parta de questões básicas que interessam à pesquisa para, em seguida, criar um amplo campo de questionamentos, advindos das respostas, e que leve ao aprofundamento analítico dos dados. Essa técnica torna-se bastante eficiente, pois traz uma maior flexibilidade, permitindo que as perguntas sejam repetidas ou esclarecidas; obtém assim dados que não seriam encontrados formalizados em documentos, além de oferecer mais oportunidades para avaliação do entrevistador (MARCONI; LAKATOS, 2003).

O primeiro passo para iniciar a investigação foi a elaboração de um roteiro semiestruturado para ser utilizado nas entrevistas com os sócios-gestores das lojas Endossa e Mercearia. Nesse roteiro, constavam perguntas a respeito da dinâmica de comunicação de ambos os empreendimentos: quais os instrumentos de comunicação utilizados, quais as dificuldades em termos de comunicação, quais ações gostariam de realizar, se existe e como é o processo de planejamento de comunicação, como é feita a divulgação dos expositores, entre outras.

Os encontros para as entrevistas aconteceram em meados de março de 2017. $\mathrm{Na}$ Endossa, a conversa foi com a sócia Maíra Belo - antropóloga por formação, empreendedora criativa e que além de administrar a rotina da loja também é responsável pelas postagens no Facebook e no Instagram. Na Mercearia, o encontro foi com os sócios Carolina Mullets e Gustavo Bill. Carolina é publicitária e Gustavo trabalha com eventos brasilienses, como as festas Cineme-se e Moranga, além de ser um dos criadores do grupo Boomerang no Facebook. Ambas as entrevistas foram muito descontraídas, o que permitiu uma 
flexibilização do roteiro previamente elaborado, de modo que a coleta de dados foi bastante rica e proveitosa sob inferências que extrapolaram o âmbito comunicacional e possibilitaram um conhecimento mais aprofundado da estrutura organizacional.

A entrevistada da Endossa, Maíra, citou que a comunicação contribui fortemente para o desenvolvimento da imagem da marca, seu posicionamento, reconhecimento, aumento nas vendas e fortalecimento da relação com expositores e clientes. Ela ressaltou que há uma dificuldade em termos de disponibilidade de recursos financeiros, tendo em vista que o lucro de uma loja colaborativa é sempre fixo. Segundo Maíra, isso impede que contratem um profissional para gerir a comunicação adequadamente. Os pontos de maior dificuldade quando envolvidos os instrumentos de comunicação - citados por ela foram o planejamento de comunicação, o conteúdo e a linguagem do Facebook, monitoramento e avaliação de ações de comunicação e o desconhecimento dos processos de Assessoria de Imprensa, que, segundo ela, seria um instrumento fundamental para alcançar novos públicos de interesse.

Ainda segundo a entrevistada, eles precisam lidar diariamente com um número de mensagens e $e$-mails muito grande. Assim sendo, ela destaca como seria importante possuir um canal de comunicação que fosse capaz de esclarecer dúvidas e fornecer informações institucionais de maneira simples e objetiva. Por ser uma franquia, a Endossa Brasília não possui um site próprio. Para a comunicação com os expositores, a Endossa utiliza o WhatsApp, porém o considera um canal muito informal.

A entrevista na Mercearia revelou uma comunicação mais estruturada que a Endossa. Carolina citou como a comunicação está sendo fundamental para atrair novos clientes e consolidar a marca, que está há cerca de onze meses no mercado. Segundo ela, nos primeiros meses as pessoas frequentavam a loja em razão das marcas que estavam expondo e, na época da entrevista, ela disse já ter sentido que os novos clientes estavam vindo por conta da proposta e pela marca Mercearia. Nesse sentido, ela disse sentir falta de ter um funcionário responsável somente pela estruturação e pelo planejamento da comunicação, pois, de acordo com Carolina, mesmo sendo publicitária ela não consegue colocar tudo em prática, uma vez que também cuida de toda a parte administrativa e rotineira da loja.

Carolina comentou que, antes da inauguração, eles chegaram a fazer um plano de comunicação, porém, como estava muito ligado à idealização da loja, muitas ações não foram revistas e, portanto, não foram executadas. Durante a entrevista, Gustavo falou muito sobre o mercado colaborativo e sobre a pouca informação existente, mas também falou que eles vêm notando um aumento do interesse das pessoas sobre temas correlatos - colaboratividade, ocupação de espaços públicos, novos estilos de vida. Assim como a Endossa, a questão 
financeira e o planejamento também foram citados como dificuldades. Um ponto que chamou à atenção foi o fato da Mercearia fazer eventos constantes para os públicos externo e interno. Segundo os entrevistados, a realização de eventos mercadológicos (voltados para clientes) e de cunho institucional, de prospecção e capacitação (voltados para funcionários e expositores), está entre os objetivos organizacionais.

Outro ponto que se destacou foi que todos os entrevistados ressaltaram que ao pensar em comunicação de lojas colaborativas é fundamental pensar em rede e aproveitar o networking para conseguir realizar ações satisfatórias. De modo geral, eles consideram muito importante articular parcerias em diversos níveis para a manutenção de uma loja colaborativa.

As entrevistas foram fundamentais para a aproximação com a realidade das lojas colaborativas. Dessa forma, o conteúdo do Guia foi delineado considerando-se os principais pontos levantados pelos entrevistados, alinhando os processos de comunicação das lojas colaborativas Endossa e Mercearia e os resultados da pesquisa sobre o tema. As entrevistas ajudaram a criar relações complementares a respeito da comunicação nesse tipo de espaço colaborativo. O fato de as duas lojas colaborativas estarem em segmentos distintos - moda e gastronomia - contribuiu fortemente para uma percepção mais ampla sobre o mercado colaborativo. Isso leva a crer que o conteúdo do Guia atua como uma ferramenta multissegmentada, podendo ser aplicado em diferentes lojas colaborativas dos mais diversos tipos.

\subsection{A identidade visual do Guia}

Para buscar referências textuais e visuais para o conteúdo disposto no Guia, foi realizada uma pesquisa na internet e um benchmarking - análise que busca as melhores referências para aperfeiçoar o desempenho de processos, produtos, etc. (ZAGO et al., 2008) de outros manuais de comunicação e de outras áreas já produzidos. Essa análise teve como objetivo a coleta de informações para ampliar a compreensão e a percepção acerca da linguagem utilizada nesses instrumentos e adequar seu uso ao Guia desenvolvido.

A diagramação do Guia buscou seguir um layout minimalista e modular, pensado para ser disponibilizado na web. O Guia utilizou uma paleta de cores simplificada, com quatro cores: violeta, laranja, cinza escuro e cinza claro. A cor violeta foi escolhida em razão de seu significado, que se relaciona com sabedoria, poder, autenticidade, visão e qualidade (FRASER; BANKS, 2007); por sua vez, a cor laranja remete à sociabilidade, à diversão, à 
alegria e à transformação e é muito chamativa; e o cinza está associado à teoria (HELLER, 2013) e à neutralidade psicológica (FRASER; BANKS, 2007).

A capa busca trazer um jogo visual entre cubos e colmeias. Ambos foram pensados para remeter à colaboratividade: os cubos pela forma como os produtos são expostos nas lojas colaborativas; e as colmeias, por representarem a cooperação e a harmonia existente nas colônias de abelhas (PIFANO). Esses elementos são utilizados também internamente, nas páginas que sinalizam a divisão dos capítulos e dos tópicos.

O uso elegante do gradiente na capa, nos capítulos e em pontos específicos e de destaque foi escolhido por ser considerado uma tendência de design (YAMASHIRO, 2017), aliado a uma paleta de cores vívidas, como é o caso do Guia. Os elementos visuais internos também fazem referência ao formato das lojas colaborativas visitadas e à maneira como os produtos são apresentados, em nichos ou "caixinhas" quadrados ou retangulares. Internamente, o Guia apresenta algumas ilustrações e figuras de bancos de imagem da internet com características do flat design, que prioriza a simplicidade.

O design minimalista e a leveza da leitura foram priorizados, de forma que os textos estão distribuídos ao longo das páginas para que ficassem curtos, com alinhamento justificado, hifenizado e com fonte na cor cinza para tornar a leitura mais fluida e para não carregar visualmente, como ocorreria com o uso da cor preta. Como a característica da publicação é ser mais jovem e moderna, as fontes escolhidas não são serifadas. A tipografia utilizada para títulos e subtítulos é a família Gotham em diferentes pesos. Para o corpo do texto, foi utilizada a fonte Lato, que também não possui serifa e possui boa legibilidade ainda que em tamanho reduzido. No caso do Guia, foi utilizado corpo 14. Como a letra sem serifa precisa de maior espaçamento para boa leitura (WHITE, 2006), este foi trabalhado em 18 pt. 


\subsection{Avaliação do conteúdo}

Após a finalização da escrita do conteúdo do Guia, ele foi enviado para uma avaliação de conteúdo para que fossem analisadas a linguagem e as práticas propostas pelo produto. $\mathrm{O}$ ideal era que o avaliador fosse uma pessoa que trabalhasse com economia criativa/colaborativa. Nesse caso, a sugestão do avaliador levava em consideração o perfil do público-alvo do Guia.

Para a avaliação, solicitou-se que a pessoa fizesse uma leitura atenta de todo o Guia e destacasse os pontos de dúvidas e/ou dificuldade de compreensão de termos, frases e conceitos. A sócia da Endossa, Maíra Belo, aceitou avaliá-lo e recebeu uma cópia, porém não devolveu o guia com as observações até o fechamento deste trabalho.

\subsection{Distribuição do Guia}

O Guia de Boas Práticas de Comunicação para Lojas Colaborativas foi disponibilizado na plataforma Issuu. A utilização deste canal justifica-se pelo conceito de colaboratividade e de redes sociais que engloba as lojas colaborativas e todo o processo de desenvolvimento deste Guia e que está também presente no Issuu.

O Issuu é uma plataforma que se assemelha às livrarias e às bancas digitais. Nele estão disponibilizados milhares de livros, guias, revistas e os mais diversos conteúdos destinados à leitura. No Issuu é possível ler, curtir, compartilhar em outras redes sociais e fazer download gratuitamente. Além disso, ele funciona como uma rede social, tendo em vista que é possível seguir perfis de usuários, explorar e buscar conteúdos dentre várias categorias e coleções, como arte, automóvel, beleza, casa, ciência, entretenimento, espiritualidade, educação, feminismo, gastronomia, moda, negócios, saúde, sociedade, tecnologia, viagem e muitas outras. A busca também é simples: existem filtros por idiomas, relevância e classificação etária.

Interativo e moderno, o Issuu oferece uma estrutura perfeita para leitura, sendo possível visualizar em tela cheia e clicar para virar as páginas, posicionando o mouse sobre a lateral direita ou esquerda do Guia e clicando. Um botão para avançar e retroceder também está disponível, permitindo uma experiência agradável ainda que o arquivo tenha um grande número de folhas. Ainda é possível ir a qualquer página clicando na barra de rolagem inferior, fazer busca de palavras específicas e dar zoom.

A leitura do Guia ainda é facilitada por meio do direcionamento para a seção que o usuário deseja, clicando no título do sumário, onde está disponibilizado um link para a página 
correspondente. Apesar de estar disponível apenas em inglês, a ferramenta é muito simples e intuitiva, o que permite encontrar o conteúdo desejado de forma simplificada e fazer a busca em português. A plataforma também permite a criação de "pilhas de livros e revistas" (stacks) para leitura posterior, para fazê-lo basta clicar na foto do perfil e adicionar à lista.

O Issuu oferece estatísticas de acesso e leitura ao conteúdo publicado e pode ser acessado em desktop e em dispositivos mobile como smartphones (Android e iOS) e tablets pelo aplicativo próprio.

Link:

https://issuu.com/feliciamacedo/docs/guia_comunicacao_lojas_colaborativa 


\section{CONSIDERAÇÕES FINAIS}

Ao longo deste memorial foram descritas todas as etapas do processo de criação - da ideia, passando pelo desenvolvimento até a distribuição - de um produto de comunicação pensado para gestores de lojas colaborativas que desejam estruturar e profissionalizar sua comunicação, melhorando o relacionamento com os diversos públicos que um empreendimento desse tipo tem: clientes finais, expositores, funcionários, parceiros, sociedade em geral, etc.

Por ser um mercado em desenvolvimento, ajudar as lojas colaborativas na compreensão do papel transformador e integrador da comunicação é um importante passo para contribuir para a consolidação do segmento e o fortalecimento dos ideais que envolvem a criatividade e a colaboratividade. O processo de amadurecimento precisa estar alinhado a uma comunicação com propósito, orientada pelos rumos do planejamento e guiada pelo relacionamento, almejando potencializar a inovação intrínseca ao mercado criativo.

Este estudo proporcionou aprofundamento dos conhecimentos acerca da Comunicação, da Economia Criativa e do Consumo Colaborativo. Os métodos e as técnicas de pesquisa aplicados neste estudo também possibilitaram uma maior familiaridade com a estrutura comunicacional e organizacional de uma loja colaborativa. Os processos de comunicação, os instrumentos utilizados, as principais dificuldades e os anseios dos sóciogestores das lojas colaborativas Endossa e Mercearia foram analisados de modo que fosse possível traçar as relações existentes entre todas as variáveis e, por fim, elencar os itens que fariam parte do conteúdo do Guia e seriam mais importantes para lojas colaborativas de qualquer segmento.

Foi bastante desafiador definir e apresentar neste trabalho de conclusão de curso a proposta de um guia de comunicação voltado para um mercado tão recente em Brasília e no Brasil. Contudo, o trabalho árduo permitiu que o Guia fosse desenvolvido com uma linguagem objetiva - que pudesse ser compreendida por pessoas que estão vivenciando um contato inicial com a comunicação e que mostrasse os benefícios que uma boa comunicação pode trazer a uma organização - e com uma estética moderna e atrativa, que remetesse ao objeto de estudo, e assim respondesse de forma adequada ao problema desta pesquisa.

Nesse sentido, o Guia mostra aos gestores, considerando o cenário das lojas colaborativas - onde, muitas vezes, a disponibilidade de recursos financeiros é limitada e não há uma equipe dedicada exclusivamente à comunicação -, algumas técnicas, procedimentos, estratégias e boas práticas para serem usadas na gestão da comunicação. Tudo isso levando 
em consideração as particularidades e apresentando soluções voltadas para o mercado criativo e colaborativo propriamente, o que um Guia de comunicação menos direcionado talvez não abrangesse. O produto foi sendo pensado e construído para ser uma fonte de informação e oferecer estratégias e ações de fácil execução. Com isso, espera-se que se desenvolva uma cultura de comunicação integrada nesses empreendimentos que valorize ainda mais as contribuições e os benefícios que uma comunicação bem feita pode trazer às organizações.

Durante os meses de execução deste trabalho, a importância de desenvolver um Guia de comunicação especializado nas lojas colaborativas tornou-se ainda mais palpável. É notável que o número de lojas colaborativas começou a crescer e ganhar espaço na mídia: o Nós - Mercado Criativo começou em uma entrequadra comercial e hoje se mudou para o Shopping Iguatemi Brasília; lojas tradicionais como a VerdeManga reinventaram seus conceitos e reabriram em formato colaborativo e pop-up (temporário) em alguns shoppings da cidade; a Lojinha ViradaVerde começou como uma feira de rua e hoje possui espaço físico no Sudoeste, entre outras.

Este é apenas o fechamento de um ciclo, mas não o fim da jornada. Este trabalho ainda pode contribuir para o estímulo e o aprofundamento de novas pesquisas sobre como atua e se molda a Comunicação em novos espaços de trabalho e gestão, inclusive em outros espaços colaborativos que não só as lojas.

Finalizo este trabalho e este curso ressaltando que esta pesquisa me motivou a ver como a diversidade, a inovação, o sentimento de comunidade e a cidadania em que a colaboratividade está baseada são essenciais para gerar impactos na vida das pessoas, seja em pequenos seja em grandes espaços. E não há melhor maneira de fazê-lo se não com a Comunicação. 


\section{REFERÊNCIAS}

ADORNO, Marina. Artistas ganham visibilidade em lojas colaborativas espalhadas pela cidade. Correio Braziliense, 21 maio 2017. Disponível em: <http://www.correiobraziliense.com.br/app/noticia/revista/2017/05/21/interna_revista_correi o,596366/lojas-colaborativas-em-brasilia.shtml>. Acesso em: 7 jun. 2017.

BOTSMAN, Rachel; ROGERS, Roo. O que é meu é seu: como o consumo colaborativo vai mudar o nosso mundo. Porto Alegre: Bookman, 2011.

CAVALCANTI, Glauce. Economia criativa avança mesmo durante a recessão. Rio de Janeiro: O Globo, 2016. Disponível em: <http://oglobo.globo.com/economia/economiacriativa-avanca-mesmo-durante-recessao-18399357>. Acesso em: 10 jan. 2017.

Federação das Indústrias do Estado do Rio de Janeiro (FIRJAN). Mapeamento da indústria criativa no Brasil: diagnósticos e mapeamentos setoriais. Rio de Janeiro: Sistema FIRJAN, 2016. Disponível em: <http://www.firjan.com.br/economiacriativa/download/mapeamentoindustria-criativa-sistema-firjan-2016.pdf> Acesso em: 15 jan. 2017

Mapeamento da indústria criativa no Brasil. Rio de Janeiro: Sistema Firjan, 2014. Disponível em: <http://www.abradi.com.br/wp-content/uploads/2015/05/Mapeamento2014.pdf >. Acesso em: 16 jan. 2017.

FRASER, Tom; BANKS, Adam. O guia completo da cor. Tradução de Renata Bottini. São Paulo: Editora Senac São Paulo, 2007.

GASPARINDO, Leila. A gestão da comunicação no estímulo à cultura de inovação nas empresas brasileiras da indústria criativa. In: Congresso da Associação Brasileira de Pesquisadores de Comunicação organizacional e de Relações públicas, 17-20 maio 2016: São Paulo, SP. Anais do 10 ${ }^{0}$ Abrapcorp: comunicação, economia criativa e organizações. Organizadores: Luiz Alberto de Farias, Valéria de Siqueira Castro Lopes. Dados eletrônicos. Porto Alegre: EDIPUCRS, 2016, p. 343-363. Disponível em: <http://ebooks.pucrs.br/edipucrs/Ebooks/978-85-397-0871-0.pdf>. Acesso em: 16 jan. 2017. 
GIL, Antônio Carlos. Métodos e técnicas de pesquisa social. 6. ed. São Paulo: Atlas, 2008.

HELLER, Eva. A psicologia das cores: como as cores afetam a emoção e a razão. 1. ed. Tradução de Maria Lúcia Lopes da Silva. São Paulo: Gustavo Gili, 2013.

IASBECK, Luiz Carlos Assis. Identidade organizacional e a construção dos discursos institucionais. In: KUNSCH, Margarida M. Khroling (Org.). Comunicação organizacional: linguagem, gestão e perspectivas, v. 2. São Paulo: Saraiva. 2009. p. 7-31.

KUNSCH, Margarida Maria K. Planejamento de relações públicas na comunicação integrada. São Paulo: Summus, 2003.

MARCONI, Marina de Andrade; LAKATOS, Eva Maria. Fundamentos de metodologia científica. 5. ed. São Paulo: Atlas, 2003.

NASSAR, Paulo. Conceitos e processos de comunicação organizacional. In: KUNSCH, Margarida M. Krohling Org.). Gestão estratégica em comunicação organizacional e relações públicas. 2. ed. São Caetano do Sul, SP: Difusão Editora, 2009. p. 61-77.

OLIVEIRA, João Maria de; ARAÚJO, Bruno César de; SILVA, Leandro Valério. Panorama da economia criativa no Brasil. Brasília: Rio de Janeiro: Ipea, 2013. Disponível em: <http://www.ipea.gov.br/portal/images/stories/PDFs/TDs/td_1880.pdf> Acesso em: 10 jan. 2017.

PEDRADA, Thaís. Endossa: conheça a loja colaborativa que faz sucesso em diferentes cidades brasileiras. Disponível em: <http://www.morangodela.com/2014/06/endossaconheca-loja-colaborativa-que.html>. Acesso em: 7 jun. 2017.

PELLICANO, Raquel. Disponível em: <http://business.google.com/website/merceariacolaborativa/> Acesso em: 6 jun. 2017.

PIFANO, Joaquim. Abelhas: mestres em cooperação. Geração Coop. Disponível em: <http://www.geracaocoop.pt/sabias-que/abelhas-mestres-em-cooperacao>. Acesso em: 6 jun. 2017. 
REGO, Francisco Gaudêncio Torquato do. Comunicação empresarial/comunicação institucional: conceitos, estratégias, sistemas, estrutura, planejamento e técnicas. São Paulo: Summus, 1986.

- Da gênese do jornalismo empresarial e das relações públicas à comunicação organizacional no Brasil. In: KUNSCH, Margarida M. Khroling (Org.). Comunicação organizacional: histórico, fundamentos e processos, v.1. São Paulo: Saraiva. 2009. p. 7-28.

RIBEIRO, Milton. Planejamento visual gráfico. 10. ed. atual. Brasília: Linha Gráfica e Editora, 2007.

ROMAN, Artur Roberto. Organizações: um universo de discursos bem-ditos, mal-ditos e não ditos. In: KUNSCH, Margarida M. Krohling (Org.). Comunicação organizacional: linguagem gestão e perspectivas, v. 2. São Paulo: Saraiva, 2009. p. 125-159.

SAMPAIO, Lucas. Em franco crescimento, economia criativa puxa busca por profissionais. São Paulo: O Estadão, 2015. Disponível em:

$<$ http://economia.estadao.com.br/blogs/radar-do-emprego/2015/02/23/em-francocrescimento-economia-criativa-puxa-busca-por-profissionais/>. Acesso em: 18 jan. 2017.

SANTANA, Paula. Viva Endossa. GPS Brasília, 29 março 2016. Disponível em: <http://paulasantana.gpsbrasilia.com.br/news/p:0/idp:36949/nm:Viva-Endossa> Acesso em: 6 jun. 2017.

SITE. Brasil quer dobrar investimento em economia criativa. Belo Horizonte: O Tempo, 2012. Disponível em: <http://www.otempo.com.br/capa/economia/brasil-quer-dobrarinvestimento-em-economia-criativa-1.335524>. Acesso em: 10 jan. 2017.

SITE. Minhocco. Disponível em: <http://www.minhocco.com.br/es/lojas/>. Acesso em: 6 jun. 2017.

WHITE, Jan V. Edição e design: para designers, diretores de arte e editores - o guia clássico para ganhar leitores. São Paulo: JSN Editora, 2006. 
YAMASHIRO, Agatha. Tendências no design em 2017. Design'on. Disponível em: <https://www.des1gnon.com/2017/02/tendencias-no-design-em-2017/>. Acesso em: 6 jun. 2017.

ZAGO, Camila Avozani; SILVA, Vanina Durski; COELHO, Leandro Callegari; FOLLMANN, Neimar; RODRIGUEZ, Carlos Manuel Taboada. Benchmarking: uma perspectiva de avaliação de desempenho logístico. 2008. Disponível em: <http://www.aedb.br/seget/arquivos/artigos08/516_516_benchmarking_logistico_seget.pdf $>$. Acesso em: 7 jun. 2017. 


\section{APÊNDICE A - ROTEIRO DE ENTREVISTAS}

1. Quais instrumentos de Comunicação vocês usam?

Comunicação Institucional

- Relações Públicas

- Assessoria de Imprensa

- Publicidade/Propaganda institucional

- Gestão de imagem corporativa

- Marketing Social

- Marketing Cultural

- Jornalismo Empresarial

- Mídias sociais (quais?)

- Website

Comunicação Mercadológica

- Marketing

- Merchandising

- Visual merchandising

- Pesquisa de mercado

- Estratégias de lançamento

- Promoção de vendas

- Publicidade

- Eventos, feiras,

- Pós-venda

- Mídias sociais

2. Quem são os responsáveis pela da comunicação?

3. Como você avalia a contribuição que a comunicação faz para a empresa?

4. Quais as principais dificuldades que encontram relacionadas à comunicação?

5. Há planejamento para a comunicação (objetivos específicos)? Está relacionado aos objetivos organizacionais?

6. Como lidam/planejam a comunicação com tantos públicos (clientes, expositores, funcionários etc.)?

7. Como vocês definem quais expositores serão "anunciados" nas mídias?

8. Existe algum instrumento de Comunicação que gostariam de utilizar, mas não o fazem por desconhecimento de seu funcionamento? 